\title{
Application of the Multiplex Polymerase Chain Reaction (M-PCR) for the Screening of Vibrio spp. from Rivers in Kuching, Sarawak
}

\author{
MICKY VINCENT*, LAWRANCE TUAH, CHRISTY CHAN SIEN WEI, \\ LESLEY MAURICE BILUNG \& KASING APUN
}

\author{
Department of Molecular Biology, Faculty of Resource Science and Technology, Universiti Malaysia \\ Sarawak, 94300 Kota Samarahan, Sarawak, Malaysia
}

\begin{abstract}
The present study was conducted to investigate the occurrence of Vibrio spp. from selected rivers in Kuching, Sarawak (Malaysia) using Multiplex Polymerase Chain Reaction (m-PCR). During the six month study period, 19 samples were collected monthly from seven rivers, followed by simultaneous detection of three Vibrio spp., Vibrio parahaemolyticus, Vibrio cholerae and Vibrio vulnificus, in a single tube PCR reaction. Three sets of primers targeting the thermolabile $(t l)$, outer membrane protein $($ omp W) and hemolysin/cytolysin genes (vulCulsl) of $V$. parahaemolyticus, $V$. cholerae and $V$. vulnificus, respectively, were used. The results indicated that $V$. parahaemolyticus was the predominant species, occurring approximately $60.9 \%$ throughout the sampling period, followed by $V$. cholerae $(23.1 \%)$ and $V$. vulnificus $(16.0 \%)$. The months of July and December were found to be the months where all three Vibrio spp. were found to be at higher frequencies in the river samples. Results analyzed also indicated that the rivers with the highest prevalence of the three Vibrio spp. were Tambak Sejingkat, followed by Sungai Jernang and Sungai Tabuan. We conclude that m-PCR is a powerful and useful tool for the rapid and simultaneous detection of $V$. parahaemolyticus, $V$. cholerae and $V$. vulnificus from the riverine environments without the need for isolation and culturing. Furthermore, this method is highly specific, and could be applied in diagnostic laboratories for larger scale epidemiological investigations of Vibrio spp.
\end{abstract}

Keywords: Multiplex PCR (m-PCR), Vibrio cholerae, Vibrio parahaemolyticus, Vibrio spp., Vibrio vulnificus

\section{INTRODUCTION}

Vibrio spp. are Gram-negative, rod or curve shaped facultative halophilic anaerobes (Vincent et al., 2014; Malcolm et al., 2015). These bacteria are autochthonous microbial inhabitants of temperate estuarine ecosystems, brackish water, saltwater environments and coastal areas (Micky et al., 2014; Shaw et al., 2015). According to Lopez-Hernandez et al. (2015), vibrios can remain in a viable state in the marine environment for extended periods of time. Vibrio spp. are resistant to alkaline environments but do not tolerate acidic conditions and will die rapidly in solutions with $\mathrm{pH}$ lower than six. Different ecological parameters such as nutrient, temperature, salinity, zooplankton and phytoplankton concentration also have direct influence on the presence and abundance of Vibrio spp. in the environment (Alam, 2003; Lopez-Hernandez et al., 2015). Warmer temperature quickly increases the concentration of Vibrio spp. in both molluscan shellfish and seawater. It was also reported that fewer Vibrio spp. were cultured when temperature drop and low salinity are recorded (Alam, 2003). However, the degree of salt tolerance varies among the species of this genus.

Outbreaks of Vibrio associated diseases present public health problems in many countries, such as United States, India, Bangladesh, Canada, Africa, Latin America and Malaysia (Son et al., 2002; Micky et al., 2014; Lopez-Hernandez et al., 2015). These diseases are usually associated with contaminated or improperly cooked seafood, especially raw seafood, such as raw oysters and also domestic use of highly polluted waters (Lesley et al., 2011; Shaw et al., 2015; Malcolm et al., 2015). Vibrio spp. that are implicated in these cases are numerous. However, the three species that are of major concerns are $V$. parahaemolyticus, $V$. cholerae and $V$. vulnificus. 
Vibrio parahaemolyticus is an opportunistic foodborne pathogen, and is often present in marine reservoirs, mainly shellfish (Vincent et al., 2015). It was first discovered in the 1950s during a shirasu food poisoning outbreak (Malcolm et al., 2015). Pathogenic $V$. parahaemolyticus cause severe diarrhea, abdominal cramps, nausea, vomiting, headaches, fever and chills in human via the production of several toxins such as thermo labile $(t l)$ toxin, thermo stable direct hemolysin $(t d h)$ and tdh-related hemolysin (trh) (Micky et $a l ., 2014)$. This species is reported to be the leading cause of seafood-associated bacterial gastroenteritis in the world (DePaola et al., 2003).

$V$. cholerae is another member of the Vibrio family that is distributed worldwide in the estuarine environment (Vincent et al., 2014). Pathogenic $V$. cholerae, such as $V$. cholerae $\mathrm{O} 1$ and $V$. cholerae $\mathrm{O} 139$, are important agents that cause potentially fatal diarrhea in human. The virulence factor of $V$. cholerae, especially group 01, is distinct from other genus (Bilung et al., 2014). This particular species produce several toxins such as cholera toxin $\mathrm{A}(\operatorname{ctx} \mathrm{A})$, cholera toxin $\mathrm{B}(c t x \mathrm{~B})$, accessory cholera enterotoxin (ace) and zonula occludens toxin (zot) that cause bloodless, watery diarrhea, voluminous watery stools, and muscle cramps (Radu et al., 1999; Son et al., 2002; Vincent et al., 2014). This bacterium continues to be prevalent in many underdeveloped and developing countries where it has caused major cholera epidemics. For example, 245,393 cases of cholera (3,034 deaths) were reported in 2012 , and approximately $50 \%$ of these cases occurred in Africa and South America (LopezHernandez et al., 2015).

Like other members of the genus Vibrio, $V$. vulnificus is also found in the estuarine environments. This bacterium is pathogenically more severe as infections occur not only through the oral route, but also via open wounds that are exposed to warm seawater infested with this bacterium (Hlavsa et al., 2011). Upon entry, localised septicemia symptoms such as swelling, erythema and intense pain would manifest between four hours to four days. According to Shaw et al. (2015), approximately 93 serious cases of $V$. vulnificus infections are reported in the United
States annually. The same study also stated that $V$. vulnificus alone was responsible for $35 \%$ of all non-foodborne Vibrio infections (NFVIs) and $78 \%$ of NFVI deaths in the United States from 1997 to 2006. Moreover, an estimated $50 \%$ of mortality rate is reported in immuno compromised patients infected with $V$. vulnificus, topping the fatality list among the three species (Oliver, 2005).

The state of Sarawak (Malaysia), experienced a major cholera outbreak in Miri and the Northern Division from November 1997 to April 1998 (Son et al., 2002). According to Son et al. (2002), contaminated water supplies from the surrounding rivers were the main mode of transmission for the outbreak which involved $V$. cholerae 01. During this outbreak, more than 1,000 cases were reported (Son, personal communication). This outbreak and possible unreported ones are strong justifications for a need to constantly monitor the distribution of Vibrio spp. in rivers, especially its estuarine environment, where these bacteria are generally found in abundance. One recommended monitoring procedure for the detection of Vibrio spp. is to use polymerase chain reaction (PCR)-based method (Lesley et al., 2011, Micky et al., 2014). This method has proven to speed the detection of even nonculturable Vibrio spp. (Vincent et al., 2014). A more recent improvement of the conventional PCR called Multiplex PCR (m-PCR) is a technique that uses multiple pairs of primers to amplify three or more target organisms simultaneously in a single reaction (Bej et al., 1999; Lee et al., 2003). m-PCR has proven to be a rapid and highly sensitive method for specific detection of Vibrio spp. either from aquatic environments or seafood (Lee et al., 2003). In this study, m-PCR was performed on water samples collected from seven rivers during a six month study period from July, to December, 2003 in attempts to detect and monitor the distribution of several Vibrio spp. simultaneously. m-PCR reactions were performed in one-tube PCR mixtures utilizing the use of three primer pairs $(t l$, omp $W$ and vulCulsl), specifically targeting individual Vibrio spp. such as $V$. parahaemolyticus, $V$. cholerae and $V$. vulnificus (Lee et al., 1998; Bej et al., 1999; Lopez-Hernandez et al., 2015; Vincent et al., 2015). 


\section{MATERIALS \& METHODS}

\section{Collection of Samples}

Water samples were collected from several areas in Kuching, Sarawak (Malaysia) from the following sites; Sungai Bako, Sungai Jernang, Sungai Sejingkat, Tambak Sejingkat, Sungai Tabuan, Sungai Kuap and Sungai Melaban. Two to three surface water samples were collected from each sampling site, totaling to a number of 19 samples collected monthly during the six month study period (JulyDecember, 2003). The water samples were collected and stored at $4^{\circ} \mathrm{C}$ in pre-sterilized 250 $\mathrm{ml}$ Schott bottles, then transported to the laboratory and processed within 2 hours of collection.

\section{Enrichment of Water Samples}

The water samples were diluted to a 1:5 ratio in alkaline peptone water (APW, $\mathrm{pH}$ 8.5-8.6), as modified from a procedure by Atlas (1993). For each water samples, $50 \mathrm{ml}$ was added to $200 \mathrm{ml}$ of APW, mixed well and incubated at $37^{\circ} \mathrm{C}$ for 16-18 hours. Upon enrichment, $1.5 \mathrm{ml}$ of the upper layer was used for bacterial DNA extraction. In addition, $200 \mu$ of the enrichment homogenate were pipetted out from the upper layer and mixed with a mixture of LB broth with 15\% glycerol (Fluka, Switzerland) when immediate DNA extraction was not performed. These cultures were then stored at $20^{\circ} \mathrm{C}$ until further use.

\section{Genomic DNA Extraction}

Genomic DNA isolation was performed by modifying the procedure described by Ausubel et al. (1987). Overnight cultures from the processed water samples were transferred into sterile Eppendorf tubes and were centrifuged at $10,000 \mathrm{rpm}$ for $1 \mathrm{~min}$. After removing the supernatant, $700 \mu 1$ of TE buffer was added, followed by a short vortexing before adding 5 $\mu l$ of Proteinase K $(25 \mathrm{mg} / \mathrm{ml})$ and $10 \mu 1$ of $10 \%$ SDS. Next, the mixtures were incubated at $60^{\circ} \mathrm{C}$ for about $1 \mathrm{hr}$. Phenol:Chloroform: Isoamyl propanol was then added at $500 \mu \mathrm{l}$ to the mixture, followed by centrifuging at 12,000 $\mathrm{rpm}$ for $1 \mathrm{~min}$. After centrifugation, $200 \mu \mathrm{l}$ of the upper layer of the supernatant was transferred into a new tube before adding $200 \mu 1$ of $3 \mathrm{M} \mathrm{KAc}$ and $400 \mu 1$ of isopropanol, followed by a thorough mixing. The solution was then centrifuged at 12,000 rpm for another $7 \mathrm{~min}$ and the supernatant was discarded. The DNA pellet collected was then washed with $500 \mu 1$ of $70 \%$ ethanol and centrifuged for $5 \mathrm{~min}$ at 12,000 rpm. After the centrifugation, the supernatant was discarded and the pellet was dried for approximately $30 \mathrm{~min}$ before dissolving in $30 \mu \mathrm{l}$ of $\mathrm{sdH}_{2} \mathrm{O}$ and kept frozen at $-20^{\circ} \mathrm{C}$ until further use.

\section{Multiplex PCR (m-PCR) Reactions}

Table 1 below shows the properties of the specific primers, target genes, amplicon sizes, melting temperature and sources of gene sequences used for m-PCR amplification in detecting the presence of all three Vibrio spp. All primers were obtained from MWG, Germany. $\mathrm{m}$-PCR amplifications were performed in a $25 \mu \mathrm{l}$ final volume consisting of $2.5 \mu \mathrm{l}$ of $10 \mathrm{X}$ PCR reaction buffer (Promega Corporation, WI, USA), $1.0 \mu \mathrm{l}$ of each of the $5 \mathrm{pmol} / \mu \mathrm{l}$ forward and reverse primers for $t$, omp $W$ and Vulcls, 0.5 $\mu \mathrm{l}$ of $10 \mu \mathrm{M}$ dNTPs, $1.5 \mu \mathrm{l}$ of $25 \mu \mathrm{M} \mathrm{MgCl}_{2}, 0.3$ $\mu \mathrm{l}$ of $5 \mathrm{U} / \mu \mathrm{l}$ Taq DNA polymerase and $9.2 \mu \mathrm{l}$ volume of sterile distilled water. After $20 \mu \mathrm{l}$ of the m-PCR mixtures were transferred into $0.2 \mu \mathrm{l}$ PCR tubes, $5 \mu \mathrm{l}$ of DNA template from each water sample was pipetted into the respective reaction tubes. The $\mathrm{m}-\mathrm{PCR}$ reactions were run in a DNA thermal cycler (Perkin Elmer, USA), by setting the following temperature-cycling parameters: initial denaturation at $94^{\circ} \mathrm{C}$ for 3 min, then 30 cycles of amplification of each cycle consisted of denaturation at $94^{\circ} \mathrm{C}$ for 1 min, primer annealing at $50^{\circ} \mathrm{C}$ for $1 \mathrm{~min}$ and primer extension at $72^{\circ} \mathrm{C}$ for $2 \mathrm{~min}$. Following the amplification cycles, samples were kept at $72^{\circ} \mathrm{C}$ for $7 \mathrm{~min}$ to allow final extension of incompletely DNA synthesized.

\section{Visualization of m-PCR Products}

All m-PCR products were separated in a $1.7 \%$ $(\mathrm{w} / \mathrm{v})$ agarose gel electrophoresis. A DNA ladder (Promega Corporation, WI, USA) of $1 \mathrm{kbp}$ was used to determine the DNA sizes. Electrophoresis was performed using $1 \mathrm{X}$ TBE buffer and a constant voltage of $60 \mathrm{~V}$ at 2 
Table 1. Characteristics of the specific primers for the detection of Vibrio spp.

\begin{tabular}{|c|c|c|c|c|c|}
\hline Vibrio spp. & $\begin{array}{l}\text { Target } \\
\text { gene }\end{array}$ & Primer sets & $\begin{array}{l}\text { Tm } \\
\left({ }^{\circ} \mathbf{C}\right)\end{array}$ & $\begin{array}{l}\text { Amplicon } \\
\text { Size (bp) }\end{array}$ & Source \\
\hline \multirow[t]{2}{*}{ V.parahaemolyticus } & $t l-F$ & $\begin{array}{l}\text { AAAGCGGATTATGCAGAAGC } \\
\text { ACTG }\end{array}$ & 65 & \multirow[t]{2}{*}{450} & \multirow[t]{2}{*}{$\begin{array}{l}\text { Bej et al., } \\
\text { (1999) }\end{array}$} \\
\hline & $t l-R$ & $\begin{array}{l}\text { GCTACTTTCTAGCATCATTTTC } \\
\text { TCTGC }\end{array}$ & 63 & & \\
\hline \multirow[t]{2}{*}{ V. cholerae } & ompW-F & $\begin{array}{l}\text { CACCAAGAAGGTGACTTTATT } \\
\text { GTG }\end{array}$ & 63 & \multirow[t]{2}{*}{588} & \multirow{2}{*}{$\begin{array}{l}\text { Lopez- } \\
\text { Hernandez } \\
\text { et al., } \\
(2015)\end{array}$} \\
\hline & ompW-R & GAA CTT ATA ACC ACC CGC G & 53 & & \\
\hline \multirow[t]{2}{*}{ V. vulnificus } & vulClsl-F & $\begin{array}{l}\text { GCT ATT TCA CCG CCG CTC } \\
\text { AC }\end{array}$ & 59 & 222 & \multirow[t]{2}{*}{$\begin{array}{l}\text { Lee et al., } \\
\text { (1998) }\end{array}$} \\
\hline & vulClsl-R & $\begin{array}{l}\text { CCG CAG AGC CGT AAA CCG } \\
\text { AA }\end{array}$ & 59 & & \\
\hline
\end{tabular}

hour. Then, the gel was stained with ethidium bromide for $15 \mathrm{~min}$ and visualized on a UV transilluminator (Fotodyne, WI, USA) and photographed with Polaroid ${ }^{\mathrm{TM}}$ Type 667 film.

\section{RESULTS AND DISCUSSION}

In this study, the division of Kuching, Sarawak (Figure 1) in the South Western Island of Borneo was chosen because the rivers in the northern part of Kuching, such as the Sungai Bako, Sungai Jernang, Sungai Sejingkat, Sejingkat Causeway, Sungai Tabuan, Sungai Kuap and sungai Melaban are in close proximity to the sea, where the intermixing of freshwater and saltwater is common. Also, developments along the selected rivers such as constructions of factories and the blooming of human population make these areas prime sites for bacterial population studies, as river pollutions from sewage, rubbish and industrial wastes are often dumped directly into the rivers, which may be conducive to the existence and propagation of pathogenic microbes such as Vibrio spp. During the six month study period, three water samples were taken from each Sungai Bako, Sejingkat Causeway, Sungai Tabuan, Sungai Kuap and Sungai Melaban. While only two samples were taken from the smaller tributaries of Sungai Jernang, Sungai Sejingkat. In total, 114 water samples were collected and processed from the seven rivers during the period of study.
The results of the m-PCR monthly screenings of $V$. parahaemolyticus, $V$. cholerae and $V$. vulnificus from the selected rivers are shown in Figure 2, Figure 3 and Table 2. From Table 2, 15 of the surface water samples (SB1, SB3, SJ1, SJ2, SS1, SS2, TS1, TS2, TS3, ST1, ST3, SK1, SK2, SM1 and SM2) collected were positive for V. vulnificus, 13 samples (SB1, SB2, SB3, SJ2, SS1, SS2, TS1, TS2, ST2, ST3, SK1, SK2 and SM2) were positive for the presence of $V$. parahaemolyticus, while 10 samples (SB2, SJ1, SS1, TS1, TS2, ST2, ST3, SM1 and SM2) were positive for the presence for $V$. cholerae in July. In August, 17 samples were positive for the presence of $V$. parahaemolyticus (SB1, SB2, SB3, SJ1, SJ2, SS2, TS1, TS2, TS3, ST1, ST2, ST3, SK1, SK2, SK3, SM1 and SM2), 7 samples showed positive result for $V$. vulnificus (SB3, SJ1, SJ2, SS2, TS1, TS2 and ST3) with only one sample showing the presence of $V$. cholerae (TS3). While in September, 15 samples collected (SB3, SJ1, SJ2, SS2, TS1, TS2, TS3, ST1, ST2, SK1, SK2, SK3, SM1, SM2 and SM3) were positive for the presence of $V$. parahaemolyticus, and three samples (TS1, TS2 and TS3) were positive for $V$. cholerae. However, all 19 samples collected in September were negative for the presence of $V$. vulnificus. In October, all 19 samples were positive for the amplification of the $t l$ gene indicating the presence of $V$. parahaemolyticus but none were positive for $V$. cholerae and $V$. vulnificus. The 19 samples (SB1, SB2, SB3, 


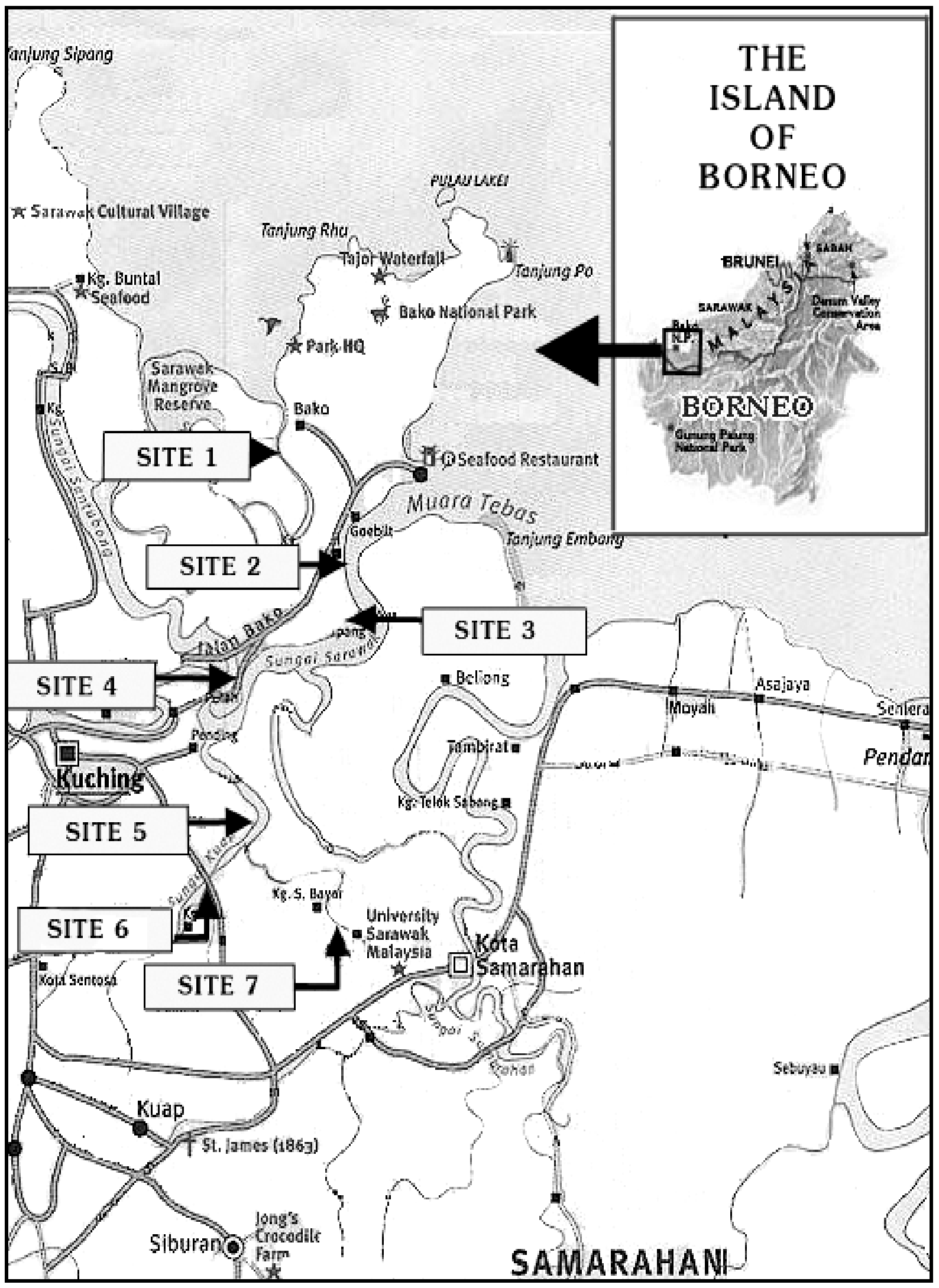

Figure 1. Location of sampling sites. Site 1 - Sg. Bako, Site 2 - Sg. Jernang, Site 3 - Sg. Sejingkat, Site 4 Tambak Sejingkat, Site 5 - Sg. Tabuan, Site 6 - Sg. Kuap, Site 7 - Sg. Melaban (Source: Google Map). 
SB3, SJ1, SJ2, SS1, SS2, TS1, ST1, ST2, ST3, SK1, SK2, SK3, SM1, SM2 and SM3) processed in November also showed that almost all samples (17 samples) were positive for the presence of $V$. parahaemolyticus with nine samples being positive for the presence of $V$. cholerae from TS1, TS2, TS3, ST1, ST2, ST3, SK1, SK3 and SM1 but none were positive for the presence of $V$. vulnificus. In December, all three Vibrio spp. were present from the collective river water samples. The majority of the samples (SB1, SB2, SB3, SB3, SJ2, TS1, TS2, ST1, ST3, SK1, SK2, SK3, SM1, SM2 and SM3) showed positive result for the presence of $V$. parahaemolyticus, followed by 13 positive results for $V$. cholerae (SB1, SB2, SB3, SB3, TS1, TS2, ST1, ST2, ST3, SK1, SK2, SK3 and SM3) and three samples (SB2, SB3 and SM1) were positive for the presence of $V$. vulnificus.

Table 3 indicates that the majority of the water samples collected from each river during the study period were positive for the presence for $V$. parahaemolyticus. Results also showed that the river with the highest prevalence of the three Vibrio spp. was Tambak Sejingkat $(V$. parahaemolyticus-77.8\%, V. cholera- $66.7 \%$, $V$. vulnificus-27.8\%), Sungai Jernang ( $V$. parahaemolyticus-83.3\%, V. cholera-8.3\%, $V$. vulnificus-33.3\%), Sungai Tabuan (V. parahaemolyticus-83.3\%, V. cholera-38.9\%, $V$. vulnificus-16.7\%) and Sungai Kuap ( $V$. parahaemolyticus-94.4\%, V. cholera-33.3\%, V. vulnificus-11.1\%) during the six month period.

The results also showed a correlation between the weather conditions with the presence of several Vibrio spp. in the river samples. These observations are also supported and have been discussed at length in a study by Lopez-Hernandez et al. (2015) and Malcom et al. (2015). During the dryer months of July and August (data unpublished), the samples collected showed the presence of almost all three Vibrio spp. Dryer climate conditions increase the level of salinity which is conducive for the growth of the three species. Interestingly, the presence of several Vibrio spp. in the rainy month differed from the dryer month. Most of the water samples collected during the rainy season (September-December) indicated the presence of $V$. parahaemolyticus and $V$. cholerae. But only few samples (3 of 76 processed samples) showed the presence of $V$. vulnificus. From Table 3 and Table 4, samples from the month of September, October, November, and December showed the presence of $V$. parahaemolyticus to be at $70 \%-90 \%$, with $15 \%$ and $68 \%$ of water samples collected in September and December being positive for the presence of $V$. cholerae. These observations suggest that $V$. parahaemolyticus and $V$. cholerae are more prevalent and dominant in the brackish waters during rainy season when, theoretically, water salinity is lower. However, water salinity level was not recorded during the course of this study. We suggest that future studies on the detection of Vibrio spp. to be done concurrently with the nutrient influx, realtime weather and river abiotic data to generate clearer correlations between the various parameters and Vibrio spp. population dynamics, as according to Lopez-Hernandez et al. (2015), concerted studies and efforts are needed to understand how biotic and abiotic factors influence Vibrio spp. population dynamics in the environments that contribute to disease epidemiology.

There have been several reports of studies being developed using PCR-based methods to directly detect only single strain of Vibrio spp. (Lee et al., 1993; Blackstone et al., 2003). However, very limited studies have used mPCR for simultaneous detection of $V$. parahaemolyticus, $V$. cholerae and $V$. vulnificus from water or environmental samples. The major challenge when using Multiplex PCR is the presence of many PCR primers in a single tube that can cause several problems such as the formation of multiple mismatching of primers, primer-dimers and other nonspecific products that may interfere with the amplification of specific products. To avoid the mismatching of the primers, all primers were pair analyzed against each other using the BlastN program from the GenBank database to rule out cross species priming. Computer analyses confirmed that all the oligonucleotide primer pairs showed significant affinities only for their target species and non-mismatch were obtained from the primers used. Furthermore, to assist in the PCR product interpretation, the sizes of the amplicons (Table 2) were initially fixed to be 


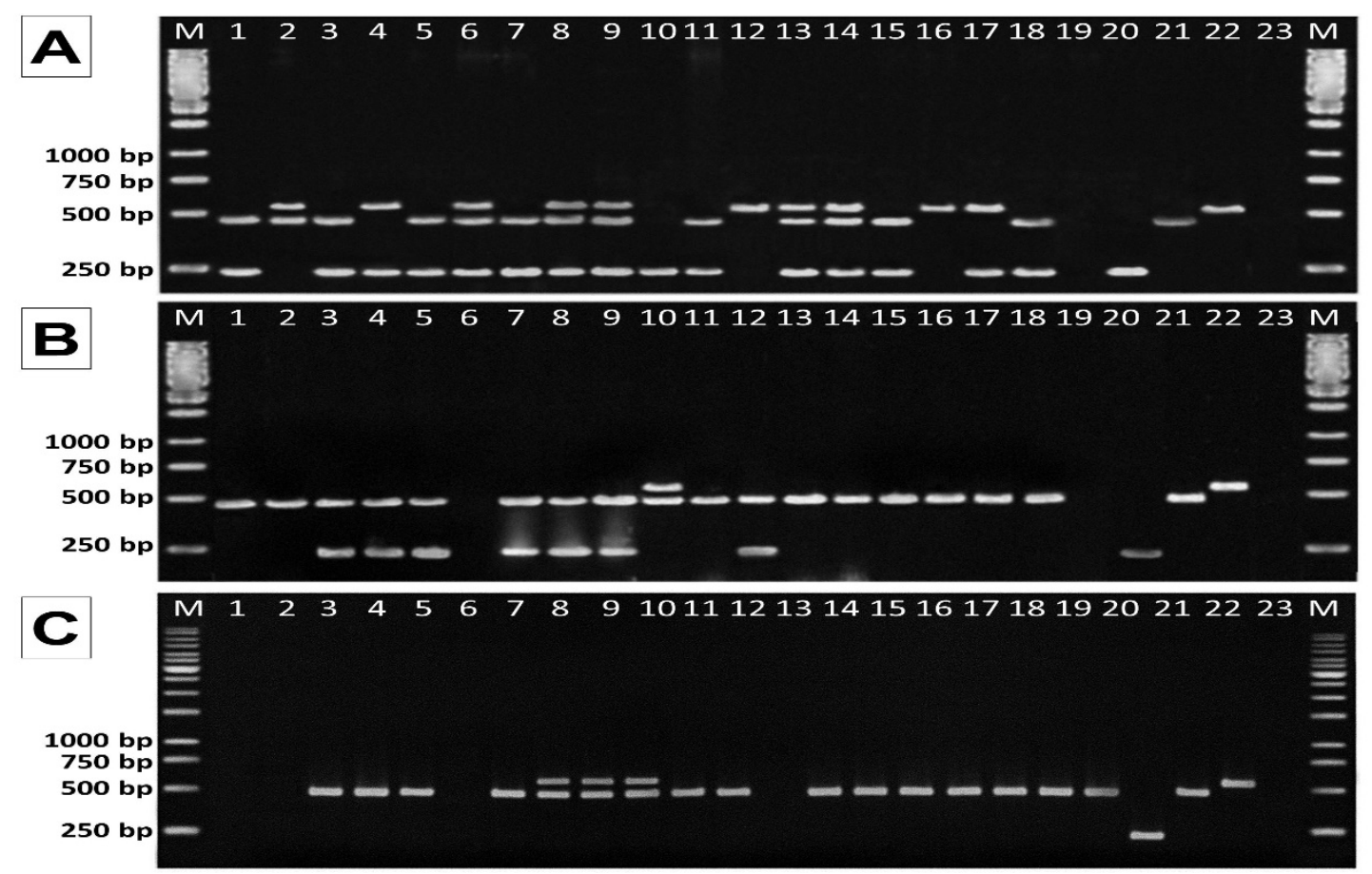

Figure 2. Agarose gel electrophoresis showing the results from PCR amplification product from samples collected in (A) July, (B) August, (C) September, 2003. Lane M - 1 kbp ladder; lane 1, 2, 3 - Sungai Bako; lane 4, 5 - Sungai Jenang; lane 6, 7 - Sungai Sejingkat; lane 8, 9, 10 - Tambak Sejingkat; lane 11, 12, 13 - Sungai Tabuan; lane 14, 15, 16 - Sungai Kuap; lane 17, 18, 19 - Sungai Melaban; lane 20 - V. vulnificus positive control; lane 21 - V. parahaemolyticus positive control; lane 22 - V. cholerae positive control; lane 23 - Negative control.

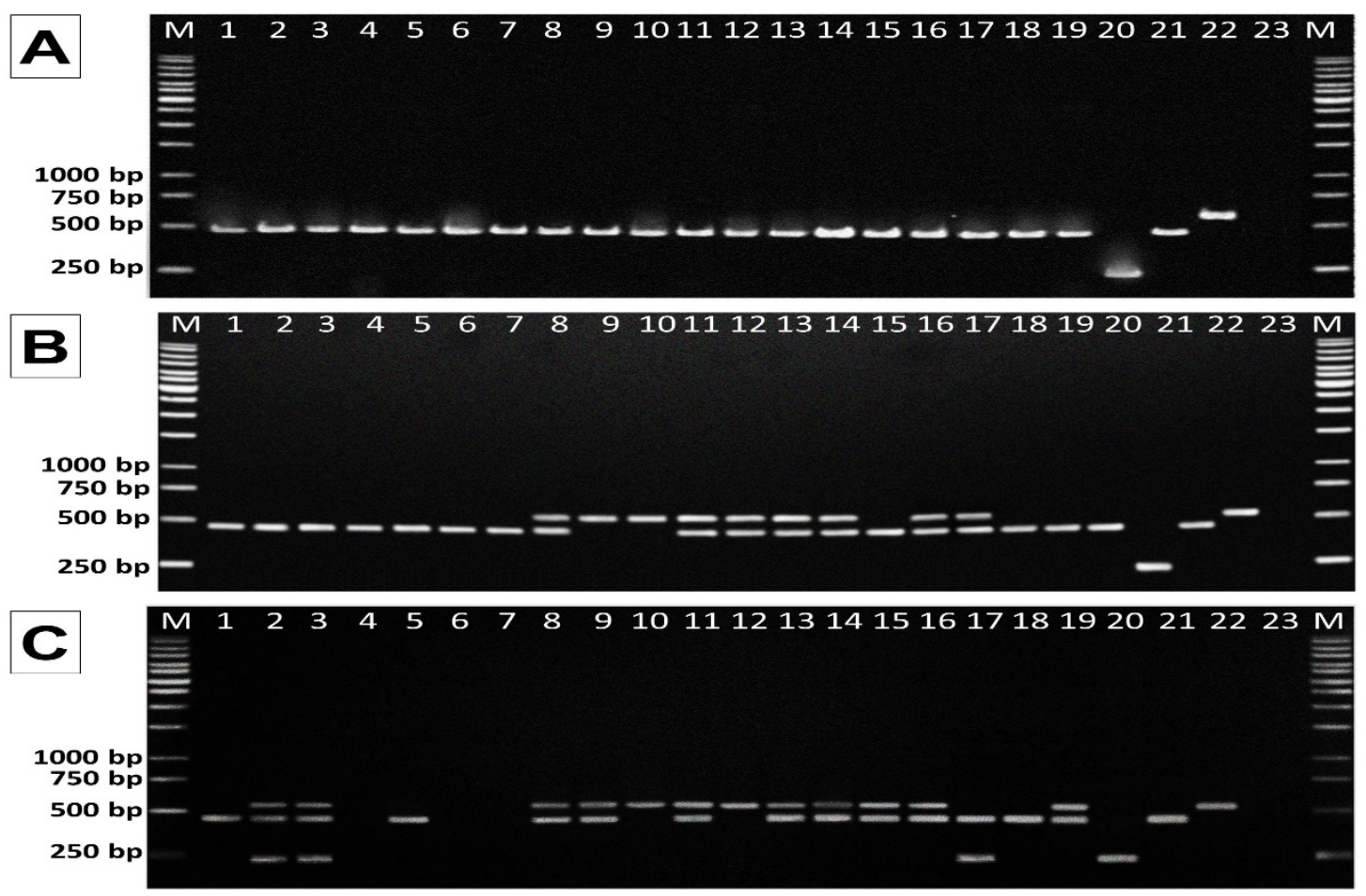

Figure 3. Agarose gel electrophoresis showing the results from PCR amplification product from samples collected in (A) October, (B) November, (C) December, 2003. Lane M - 1 kbp ladder; lane 1, 2, 3 - Sungai Bako; lane 4, 5 - Sungai Jenang; lane 6, 7 - Sungai Sejingkat; lane 8, 9, 10 - Tambak Sejingkat; lane 11, 12, 13 - Sungai Tabuan; lane 14, 15, 16 - Sungai Kuap; lane 17, 18, 19 - Sungai Melaban; lane 20 - V. vulnificus positive control; lane 21 - V. parahaemolyticus positive control; lane 22 - V. cholerae positive control; lane 23 - Negative control. 
Table 2. Detailed data of Vibrio spp. occurrence collected from July-December, 2003.

\begin{tabular}{|c|c|c|c|c|c|c|c|c|}
\hline Site Location & Samples & Vibrio spp. & Jul & Aug & Sept & Oct & Nov & Dec \\
\hline \multirow{9}{*}{ Sg. Bako } & \multirow{3}{*}{ SB1 } & V. parahaemolyticus & + & + & - & + & + & + \\
\hline & & $V$. cholerae & - & - & - & - & - & + \\
\hline & & V. vulnificus & + & - & - & - & - & - \\
\hline & \multirow{3}{*}{ SB2 } & V. parahaemolyticus & + & + & - & + & + & + \\
\hline & & V. cholerae & + & - & - & - & - & + \\
\hline & & V. vulnificus & - & - & - & - & - & + \\
\hline & \multirow{3}{*}{ SB3 } & V. parahaemolyticus & + & + & + & + & + & + \\
\hline & & V. cholerae & - & - & - & - & - & + \\
\hline & & V. vulnificus & + & + & - & - & - & + \\
\hline \multirow{6}{*}{ Sg. Jernang } & \multirow{3}{*}{ SJ1 } & V. parahaemolyticus & - & + & + & + & + & - \\
\hline & & V. cholerae & + & - & - & - & - & - \\
\hline & & V. vulnificus & + & + & - & - & - & - \\
\hline & \multirow{3}{*}{$\mathrm{SJ} 2$} & V. parahaemolyticus & + & + & + & + & + & + \\
\hline & & V. cholerae & - & - & - & - & - & - \\
\hline & & V. vulnificus & + & + & - & - & - & - \\
\hline \multirow{6}{*}{ Sg. Sejingkat } & \multirow{3}{*}{ SS1 } & V. parahaemolyticus & + & - & - & + & + & - \\
\hline & & V. cholerae & + & - & - & - & - & - \\
\hline & & V. vulnificus & + & - & - & - & - & - \\
\hline & \multirow{3}{*}{$\mathrm{SS} 2$} & V. parahaemolyticus & + & + & + & + & + & - \\
\hline & & V. cholerae & - & - & - & - & - & - \\
\hline & & V. vulnificus & + & + & - & - & - & - \\
\hline \multirow{9}{*}{ T. Sejingkat } & \multirow{3}{*}{ TS1 } & V. parahaemolyticus & + & + & + & + & + & + \\
\hline & & V. cholerae & + & - & + & - & + & + \\
\hline & & V. vulnificus & + & + & - & - & - & - \\
\hline & \multirow{3}{*}{ TS2 } & $V$. parahaemolyticus & + & + & + & + & - & + \\
\hline & & $V$. cholerae & + & - & + & - & + & + \\
\hline & & V. vulnificus & + & + & - & - & - & - \\
\hline & \multirow{3}{*}{ TS3 } & V. parahaemolyticus & - & + & + & + & - & - \\
\hline & & $V$. cholerae & - & + & + & - & + & + \\
\hline & & V. vulnificus & + & - & - & - & - & - \\
\hline \multirow{9}{*}{ Sg. Tabuan } & \multirow{3}{*}{ ST1 } & V. parahaemolyticus & + & + & + & + & + & + \\
\hline & & V. cholerae & - & - & - & - & + & + \\
\hline & & V. vulnificus & + & - & - & - & - & - \\
\hline & & V. parahaemolyticus & - & + & + & + & + & - \\
\hline & ST2 & V. cholerae & + & - & - & - & + & + \\
\hline & & V. vulnificus & - & - & - & - & - & - \\
\hline & & V. parahaemolyticus & + & + & - & + & + & + \\
\hline & ST3 & V. cholerae & + & - & - & - & + & + \\
\hline & & V. vulnificus & + & + & - & - & - & - \\
\hline & & V. parahaemolyticus & + & + & + & + & + & + \\
\hline & SK1 & V. cholerae & + & - & - & - & + & + \\
\hline & & V. vulnificus & + & - & - & - & - & - \\
\hline & & V. parahaemolyticus & + & + & + & + & + & + \\
\hline Sg. Kuap & SK2 & $V$. cholerae & - & - & - & - & - & + \\
\hline & & V. vulnificus & + & - & - & - & - & - \\
\hline & & V. parahaemolyticus & - & + & + & + & + & + \\
\hline & SK3 & V. cholerae & - & - & - & - & + & + \\
\hline & & V. vulnificus & - & - & - & - & - & - \\
\hline & & V. parahaemolyticus & - & + & + & + & + & + \\
\hline & SM1 & V. cholerae & + & - & - & - & + & - \\
\hline & & V. vulnificus & + & - & - & - & - & + \\
\hline & & V. parahaemolyticus & + & + & + & + & + & + \\
\hline Sg. Melaban & SM2 & V. cholerae & + & - & - & - & - & - \\
\hline & & V. vulnificus & + & - & - & - & - & - \\
\hline & & V. parahaemolyticus & - & - & + & + & + & + \\
\hline & SM3 & V. cholerae & - & - & - & - & - & + \\
\hline & & V. vulnificus & - & - & - & - & - & - \\
\hline
\end{tabular}


Table 3. Percentages of $V$. parahaemolyticus, $V$. cholerae and $V$. vulnificus occurrences based on sampling sites.

\begin{tabular}{|c|c|c|}
\hline Site Location & Vibrio spp. & $\%$ occurrence \\
\hline & V. parahaemolyticus & $33.3(6 / 18)$ \\
\hline \multirow[t]{3}{*}{ Sg. Bako } & V. cholerae & $22.2(4 / 18)$ \\
\hline & V. vulnificus & $27.8(5 / 18)$ \\
\hline & V. parahaemolyticus & $83.3(10 / 12)$ \\
\hline \multirow[t]{3}{*}{ Sg. Jernang } & V. cholerae & $8.3(1 / 12)$ \\
\hline & V. vulnificus & $33.3(4 / 12)$ \\
\hline & V. parahaemolyticus & $66.7(8 / 12)$ \\
\hline \multirow[t]{3}{*}{ Sg. Sejingkat } & V. cholerae & $5.6(1 / 12)$ \\
\hline & V. vulnificus & $16.7(3 / 12)$ \\
\hline & $V$. parahaemolyticus & $77.8(14 / 18)$ \\
\hline \multirow[t]{3}{*}{ T. Sejingkat } & V. cholerae & $66.7(12 / 18)$ \\
\hline & V. vulnificus & $27.8(5 / 18)$ \\
\hline & V. parahaemolyticus & $83.3(15 / 18)$ \\
\hline \multirow[t]{3}{*}{ Sg. Tabuan } & V. cholerae & $38.9(7 / 18)$ \\
\hline & V. vulnificus & $16.7(3 / 18)$ \\
\hline & V. parahaemolyticus & $94.4(17 / 18)$ \\
\hline \multirow[t]{3}{*}{ Sg. Kuap } & $V$. cholerae & $33.3(6 / 18)$ \\
\hline & V. vulnificus & $11.1(2 / 18)$ \\
\hline & V. parahaemolyticus & $83.3(15 / 18)$ \\
\hline \multirow[t]{2}{*}{ Sg. Melaban } & V. cholerae & $22.2(4 / 18)$ \\
\hline & $V$. vulnificus & $16.7(3 / 18)$ \\
\hline
\end{tabular}

different from each other in sizes making size discrimination easier by using gel electrophoresis.

When a large number of samples for screening purposes are processed to examine, individual species, the analyses may be lengthier, with higher cost for identification and confirmation. Thus identification of Vibrio spp. using m-PCR with three or more pairs of primers in the same reaction volume reduces labor, saves time, cost effective not only for specific detection of several species simultaneously but also for rapid analysis of large number of samples. In this experiment, every batch of 19 samples can be processed within 24 hour to obtain results after sampling, processing and enrichment, suggesting that $\mathrm{m}$ PCR method of identification is faster compared with traditional biochemical tests which are useful for diagnostic laboratories to detect Vibrio spp. and also for epidemiological investigations. This study has also successfully generated data on the monthly distribution of Vibrio spp. in selected rivers within the Kuching district for clinical and diagnostic laboratories use in the monitoring of $V$. parahaemolyticus, $V$. cholerae and $V$. vulnificus. 
Table 4. Overall number and prevalence of Vibrio spp. samples from July-December, 2003.

\begin{tabular}{lcccc}
\hline & V.parahaemolyticus & V.cholerae & V.vulnificus & Total \\
\hline July & 13 & 10 & 15 & 38 \\
August & 17 & 1 & 7 & 25 \\
September & 15 & 3 & 0 & 18 \\
October & 19 & 0 & 0 & 19 \\
November & 17 & 9 & 0 & 26 \\
December & 14 & 13 & 3 & 30 \\
$\begin{array}{l}\text { Total } \\
\text { Percentages of prevalence in }\end{array}$ & 95 & 36 & 25 & \\
river samples (\%) & $83.3(95 / 114)$ & $31.6(36 / 114)$ & $21.9(25 / 114)$ & \\
$\begin{array}{l}\text { Percentages of prevalence } \\
\text { among Vibrio spp. (\%) }\end{array}$ & $60.9(95 / 156)$ & $23.1(36 / 156)$ & $16.0(25 / 156)$ & \\
\hline
\end{tabular}

\section{ACKNOWLEDGEMENTS}

This work was supported by a short-term grant (grant no. 1/46/326/2002-63) from Universiti Malaysia Sarawak.

\section{REFERENCES}

Alam, M.J., Miyoshi, S.I., \& Shinoda, S. (2003). Studies on pathogenic Vibrio parahaemolyticus during a warm weather season in the Seto Inland Sea, Japan. Environmental Microbiology, 5: 706-710.

Ausubel, F.M., Brent, R., Kingston, R.E., Moore, D.D., Sideman, J., Smith, J., \& Struhl, K. (1987). Current protocols in molecular biology. New York, USA: John Wiley \& Sons. Pp 41-45.

Atlas, R.M. (1993). Handbook of microbiological media. Florida, USA:CRC Press.

Bej, A.K., Patterson, D.P., Brasher, C.W., Vickery, M.C.L., Jones, D.D., \& Kaysner, C. (1999). Detection of total and hemolysin-producing Vibrio parahaemolyticus in shellfish using multiplex PCR amplication of $t l, t d h$ and trh. Journal of Microbiological Methods, 36: 215-225.

Bilung, L.M., Fuh, Y.S., Linang, V., Benjamin, A., Vincent, M., Apun, K., Lihan, S., \& Lin, C.S. (2014). Genomic diversity of cholera outbreak strains in East Malaysia. Malaysian Journal of Medicine and Health Sciences, 10(2): 19-26.

Blackstone, G.M., Nordstrom, J.L., Vickery, M.C.L., Bowen, M.D., Meyer, R.F., \& Depaola, A. (2003). Detection of pathogenic Vibrio parahaemolyticus in oyster enrichment by real time PCR. Journal of Microbiological Methods, 53: 149-155.

DePaola, A., Ulaszek., J., Kaysner, C.A., Tenge, B.J., Nordstrom. J.L., Wells, J., Puhr, N., \& Gendel, S.M. (2003). Molecular, serological, and virulence characteristics of Vibrio parahaemolyticus isolated from environmental, food, and clinical sources in North America and Asia. Applied Environmental Microbiology, 69: 3999-4005.

Hlavsa, M.C., Roberts, V.A., Anderson, A.R., Hill, V.R., Kahler, A.M., OrrM, Garrison, L.E., Hicks, L.A., Newton, A., Hilborn, 
E.D., Wade, T.J., Beach, M.J., \& Yoder, J.S. (2011). Surveillance for water borne disease outbreaks and other health events associated with recreational water-United States, 2007-2008. Morbidity and Mortality Weekly Report Surveillance Summaries, 60: 1-32.

Lee, C.Y., Panicker, G., \& Bej, A.K. (2003). Detection of pathogenic bacteria in shellfish using Multiplex PCR followed by CovaLink NH microwell plate sandwich hybridization. Journal of Microbiological Methods, 53: 199-209.

Lee, S.E., Kim, S.Y., Kim, S.J., Kim, H.S., Shin, J,H., Choi, S,H., Chung, S.S., \& Rhee, J.H. (1998). Direct identification of Vibrio vulnificus in clinical specimens by nested PCR. Journal of Clinical Microbiology, 36(10): 2887-2892.

Lee, T. \& Pan, S.F. (1993). Rapid and specific detection of the thermostable direct hemolysin gene in Vibrio parahaemolyticus by polymerase chain reaction. Journal of General Microbiology, 139: 3225-3231.

Lesley, M.B., Velnetti, L., Cheah, Y.K., Son, R., Kasing, A., Samuel, L., Micky, V., \& Nishibuchi, M. (2011). Antibiotic resistance and plasmid profiling of Vibrio parahaemolyticus isolated from cockles (Anadara granosa) at Tanjung Karang, Kuala Selangor. International Food Research Journal, 18: 1183-1188.

Lopez-Hernandez, K.M., Pardío-Sedas, V., Lizarraga-Partida, L., de Jesús Williams, J., Martínez-Herrera, D., Flores-Primo, A., \& Uscanga-Serrano, R. (2015). Seasonal abundance of Vibrio cholerae non O1/non O139 chxA+ in oysters harvested in a coastal lagoon of Mexico's Gulf coast: A seafood safety risk concern. Food Control, 53: 46-54.

Malcolm, T.T.H., Cheah, Y.K., Radzi, C.W.J.W.M., Kasim, F.A., Kantilal, H.K., John, T.Y.H., Martinez-Urtaza, J.,
Nakaguchi, Y., Nishibuchi, M., \& Son, R. (2015). Detection and quantification of pathogenic Vibrio parahaemolyticus in shellfish by using multiplex PCR and loopmediated isothermal amplification assay. Food Control, 47: 664-671.

Micky, V., Nur Quraitu’ Aini, T., Velnetti, L., Patricia Rowena, M.B., Christy, C., \& Lesley Maurice, B. (2014). Development of a SYBR green based real-time polymerase chain reaction assay for specific detection and quantification of Vibrio parahaemolyticus from food and environmental samples. International Food Research Journal, 21(3): 921-927.

Oliver, J.D. (2005). Wound infections caused by Vibrio vulnificus and other marine bacteria. Epidemiology and Infection, 133: 383-391.

Radu, S., Lihan, S., Ho, Y.K., Yuherman, Rusul, G., Yasin, R.M., Khair, J., \& Elhadi, N. (1999). Molecular characterization of Vibrio cholerae 01 and non-01 from human and environmental source in Malaysia. Epidemiology and Infection, 123: 225-232.

Shaw, K.S., Sapkota, A.R., Jacobs, J.M., He, X., \& Crump, B.C. (2015). Recreational swimmers' exposure to Vibrio vulnificus and Vibrio parahaemolyticus in the Chesapeake Bay, Maryland, USA. Environment International, 74: 99-105.

Son, R., Micky, V., Kasing, A., Raha, A.R., Patrick, G.B., Yuherman \& Gulam, R. (2002). Molecular characterization of Vibrio cholerae 01 outbreak strains in Miri, Sarawak (Malaysia). Acta Tropicana, 83: 169-176.

Vincent, M., Lai, L.S., Ng, L.T., \& Apun, K. (2014). Application of PCR-based DNA fingerprinting techniques for the genetic differentiation of Vibrio cholerae Non01/Non 0139 isolates from Kuching, Sarawak. Borneo Journal of Resource Science and Technology, 4(2): 21-34. 
Vincent, M., Chan, C.S.W., \& Apun, K. (2015). Molecular confirmation and characterization of Vibrio parahaemolyticus from retailed fish. International Food Research Journal, 22(4): 1705-1710. 